\title{
Handover of the buildings and equipment remaining after the dissolution of the Pauline monastery in Leśna Podlaska in 1864 to the Eastern Orthodox Church and its further history
}

https://doi.org/10.34739/his.2019.08.09

\begin{abstract}
In Leśna Podlaska, the image of Mother of God has been an object of worship since 1683. In 1727, the Leśna parish was taken over by monks from the Pauline Order. In 1875, on the basis of Tsar Alexander II's decree, the church in Leśna Podlaska, together with the venerated image, the great altar, and votive offerings, were handed over to the Eastern Orthodox Church. The remaining furnishings were transferred to 18 parish churches of the liquidated dioceses of Podlasie and Lublin. The organ was transferred to All Saints Church in Warsaw. The book collection of the Pauline monks from Leśna was donated to the library of the seminary in Lublin. In the years 1879-1881, the exterior of the church was changed, giving the building an appearance characteristic of Orthodox Church temples. Leśna Podlaska became an important centre of Russification policy carried out by Russia.
\end{abstract}

Key words: Pauline monks, Pauline monastery in Leśna Podlaska, dissolution, image of Our Lady of Leśna, Eastern Orthodox Church, library, Russification policy

Monks from the Pauline order (Ordo Sancti Pauli Primi Eremita - OSPPE) came to Leśna Podlaska ${ }^{1}$ in 1727 on an initiative of Vilnius Governor and Grand Lithuanian Hetman Ludwik Konstanty Pociej. In the parish of Leśna, the image of Mother of God with Baby Jesus, carved in a small oval stone, has been worshipped since 1683 . In the $18^{\text {th }}$ and $19^{\text {th }}$ centuries, the cult of Leśna image was popular among all social groups of Catholics of both the Latin and Greek rites. The cult had primarily a local character and was a very important element of the religious practices followed by the faithful of the Roman Catholic Church and the Uniate Church in Podlasie².

\footnotetext{
* ORCID iD 0000-0003-1084-2212. weredad@interia.pl; Institute of History and International Relations, Faculty of Humanities. The results of the research carried out under the research theme No. 453/16/S were financed from the science grant granted by the Ministry of Science and Higher Education.

${ }^{1}$ The village of Leśna has been officially known as Leśna Podlaska since 1919.

2 MARAŚKIEWICZ 1988: 388-393; WRZESZCZ, ZBUDNIEWEK 2004: 868-870; BOSIACKA 2006: 207-236; WEREDA 2013: 319-330.
} 
The monastery in Leśna Podlaska was dissolved, together with 109 other monastic establishments by a dissolution order ( $u k a z$ ) signed by Tsar Alexander II on 8 November 1864 . In order to prepare the liquidation of the monasteries, a Warsawbased secret commission developed a precise plan of simultaneous liquidation of the designated units and an instruction on how to execute the plan with the help of the police, army and governmental officials.

Despite the fact that dissolutions of monasteries starting in the second half of $18^{\text {th }}$ century were common practice under the Enlightenment ideology in the countries of Europe, due to the massive scale of dissolutions and the way they were executed, Russia feared the opinions of European societies linking Russia's policy to the State-inspired persecution of the Church. In order to prevent the dissemination of information which would be detrimental for Russia, Russian diplomatic embassies received special instructions with detailed guidelines how to inform about the dissolutions presenting them as reforms necessary for the Roman Catholic Church and monastic orders. The latter were liquidated mainly due to their strong connections with the population of the Kingdom of Poland, as confirmed by the support given by the monasteries to the January Uprising fighters and the abolition of dependence of the monasteries on the order authorities in Rome. The Police Marshal General of the Kingdom of Poland and the military and police authorities he was in charge of were responsible for implementing the dissolution. Fiodor Berg, the Viceroy of the Kingdom of Poland, ordered the execution in the whole Kingdom of Poland on the night from Sunday to Monday $27 / 28^{\text {th }}$ November 1864 . On the same day, the order was announced to the public in Warsaw and Petersburg ${ }^{3}$.

The monastery in Leśna was one of seven monasteries (ones left by Augustinians-Hermits in Krasnystaw and Orchówek, Bernardines in Radecznica, Dominicans in Janów Podlaski, and the post-Reformation monasteries left in Biała Podlaska and Chełm) handed over to the faithful of the Eastern Orthodox Church ${ }^{4}$. Apart from the establishment in Krasnystaw, the other six were located in the areas inhabited by the Greek Catholic community. The takeover of the parish in Leśna Podlaska by the Eastern Orthodox Church is one of few situations (together with Chełm and Radecznica) where, apart from taking over the infrastructure, the operation of a centre of religious cult was continued.

The aim of this article is to present the processes of liquidation of the Pauline monastic centre in Leśna Podlaska, the takeover of the infrastructure, and the reception of the idea of Marian cult by the Orthodox Church. The history of the monastic facility in Leśna following its dissolution will be presented against the backdrop of Russia's policy using religious issues to accomplish its political goals and Russification.

\footnotetext{
${ }^{3}$ GACH 1984: 175-184; WEREDA 2015: 9-36.

${ }^{4}$ PREJS 2014: 369-383.
} 
Under the dissolution order of 8 November 1864 issued by Alexander II, the property of the Pauline Order in Leśna Podlaska, both movable and immovable property, came under the administration of the Treasury of the Kingdom of Poland. After the monks were removed (Władysław Kopczyński, a preacher, Dionizy Korzeniowski, the sub-prior, Atanazy Petrykowski, a preacher, Albert Mańka, a resident, Franciszek Pluciński, a preacher, Barnaba Ptakowski, the sacristian), the execution of the $u k a z$ in the Leśna Podlaska monastery was entrusted to the financial assessor of the Biała district, Aleksander Kurcewicz, and the mayor of the town of Konstantynów ${ }^{5}$. which was the poviat seat. The takeover of the monastery assets was to be assisted by Fr Garbaczewski, a representative of the local church structures, head of the Biała deanery, where the monastery was located. However, he did not submit to Kurcewicz's order. He justified his non-appearance with the lack of authorisation from the diocesan authorities (2 January 1865) ${ }^{6}$. In this way, he probably wanted to avoid legitimisation by the church authorities of the execution of Tsar's order.

The exaction of the dissolution order proceeded very fast. As early as on 3 December 1863, an inventory of movables that belonged to the dissolved Pauline monastery was compiled. Fr Dionizy Korzeniowski, the only religious in Leśna Podlaska who stayed on from among the six-person personnel, took part in the inventory-taking in addition to the members of secular authority ${ }^{7}$. His opposition to the dissolution activities, or his forced participation in the liquidation of the assets is demonstrated by an annotation he made on the inventory receipt, going beyond the accepted practice of completing inventory documentation, saying: 'in witness of receipt ${ }^{\circ}$.

The formalities related to the acquisition of the assets were completed very quickly. Already on 13 January 1865 the financial assessor summoned Fr Korzeniowski, the administrator of the Leśna Podlaska parish to sign the property seizure documentation. The monk refused to affix his signature excusing himself as not being authorised by the diocesan authorities (14 January 1865) ${ }^{9}$. The efficient acquisition procedure of the monastic property may demonstrate that the dissolution of the monastery in Leśna Podlaska was executed a plan prepared in advance.

Three monastic cells and a small garden forming part of the monastic property were allocated for the parish administrator to cater for his needs. No utility buildings were left to his $\operatorname{him}^{10}$. Depriving him of the material basis for his functioning negatively affected the religious life in this small parish counting about 80 souls.

\footnotetext{
${ }^{5}$ ADS, sygn. 432: 40-40v.

${ }^{6}$ ADS, sygn. 432: 77.

${ }^{7}$ ADS, sygn. 432: 3-4.

${ }^{8}$ ADS, sygn. 432: $48 \mathrm{v}$.

${ }^{9}$ ADS, sygn. 432: 95.

10 ADS, sygn. L. dział IV.2, Akta konsystorza generalnego diecezji lubelskiej. Fundusze budowle cmentarze kościoła parafialnego popaulińskiego w Leśnej, 1: 36.
} 
The situation did not change despite the priest's pleas at the consistory to intervene with the authorities to leave him at least one horse, a carriage and a sleigh necessary to perform religious ministry, for example, while visiting the sick. This deprivation of property also resulted in livelihood problems, which is confirmed by Fr Korzeniowski's request for permission to keep a pair of cows for his own use ${ }^{11}$. The authorities took measures to prevent the consolidation of the parish in Leśna Podlaska. On 8 December 1866, the Governmental Commission replied negatively to a proposal to incorporate the Leśna church as a filial church of the nearest parish in Bordziłówka put forward by Bishop of the Dioces of Podlasie Piotr Paweł Beniamin Szymański. The refusal was justified by the demands of the Greek Catholics to seize the church in Leśna ${ }^{12}$. The authorities also reacted negatively to a request made on 21 July 1869 by the subsequent parish administrator in Leśna Podlaska, a priest from the diocesan clergy Fr Leon Przesmycki, for permission to use additional premises ${ }^{13}$.

In the first years after the dissolution, various proposals were made for the use of the post-monastery buildings. The Governor of Siedlce and the Bishop of the Chełm Greek Catholic diocese, Mykhailo Kuziemskyi (1868-1871) both planned to transfer the post-monastery buildings to the Greek Catholic Church. It is hard to determine whether these were plans to be actually realised, or manoeuvres to spread information intended to antagonize the local Latin Rite and Greek Catholic Church communities. The implementation of a similar plan with respect to the buildings of the former Bernardine monastery in Radecznica (Diocese of Lublin) led to antagonisms between the Catholics of both rites ${ }^{14}$. Various proposals for the development of the post-monastery buildings were presented. The governor in his report to Field Marshal Fiodor Berg, the Viceroy of the Kingdom of Poland justified his proposal of handing over the Post-Pauline church for the needs of the Greek Catholic faithful whose number was greater than that of the Latin Rite population ${ }^{15}$. Bishop Kuziemskyi made attempts to take over the post-monastery buildings in order to accommodate monks staying in the Basilian monastery in Biała or as a place of isolation for the clergy of the Greek Catholic diocese of Chełm who were serving their sentences. Both proposals met with a negative response from the Ministry of the Interior. The report on this matter, addressed to Viceroy Berg and the authorities of Lublin Governorate, justified the negative decision in a broader context, making reference to the convenient location of the monastery in Leśna Podlaska, both in terms of communication and its proximity to Grodno Governorate inhabited by the Eastern Orthodox Church population. A confrontation of the post-monastery complex in Leśna Podlaska with the post-monastery buildings of the Bernardine monks in Radecznica

\footnotetext{
${ }^{11}$ ADS, sygn. 432, 432: 73.

${ }^{12}$ ADS, sygn. 432, 436: 22-23.

${ }^{13}$ ADS, sygn. L. dział IV.2: 78.

${ }^{14}$ DMITRUK 2015: 113-132.

${ }^{15}$ AGAD, Centralne Władze Wyznaniowe, sygn. 239: 708-712. 
was also performed. The edifice of the Leśna monastery was deemed 'more comfortable' (31 March/12 April 1869) ${ }^{16}$. Considerations of the possible use of the post-monastery buildings in Leśna Podlaska taking place among the highest authorities of the Kingdom of Poland show that this religious centre was part of a larger design to use it for political purposes and so was its dissolution.

In 1868, 'following various turns of events', the former monastery building, except for the rooms used by the parish administrator, was occupied for the purposes of the seat of the Witulin commune, which was transferred to Leśna Podlaska in 1866. The rooms in the building were now used as the office of the wójt, the clerk's apartment, jail, and as space for 'other needs of the commune ${ }^{17}$. Fr Przesmycki - who at the time acted as the parish administrator of in Leśna Podlaska since 1868 (after Fr Korzeniowski was removed from the position of administrator of the Ostrówka parish) - unsuccessfully tried to take over some of the monastery rooms for the needs of the parish, the organist and the church service. When the monastery was used by the commune officials, no repairs were carried out, even though the roof needed immediate repairs. The building was systematically flooded during rainfall, so it was threatened by collapse and destruction of its wooden roof and ceiling elements ( 5 July $1873)^{18}$.

After the inventory was taken, the monastery church was handed over to the parish. There are no records that the monks leaving Leśna Podlaska took with them the items of furnishing from the local temple. The inventory taken after Fr Korzeniowski left the parish in early 1869 showed that the following items of equipment were missing: a large silver gilded monstrance, large silver cross with relics of the Holy Cross, leather-bound and silver-framed missal, copy of the painting of the Blessed Virgin Mary 'on a stone', 6 albs and 1 rope for the lift. The search and the interrogation of the members of the Janów Consistory, i.e. Fathers Swiątkowski, Wierzbicki and Korzeniowski, as witnesses showed that the movables were taken away around 1865 at a verbal request of Bishop of Podlasie Piotr Beniamin Szymański to ensure their safety and placed in the vault in the bishop's seat in Janów Podlaski. He kept the painting in a private chapel, and after the dissolution of the Podlasie diocese (1867) he left for Łomża, taking it with him. The monstrance was handed over for restoration by the bishop to the dean and pastor of the Międzyrzec Podlaski parish, Fr Kazimierz Dobrowolski. The latter died soon and the monstrance probably remained in Międzyrzec Podlaski ${ }^{19}$. Steps were taken to recover the rope borrowed by Fr Korzeniowski, but the albs were made into surplices, as these were needed by

\footnotetext{
${ }^{16}$ ADS, sygn. L. dział IV.2: 36.

${ }^{17}$ ADS, sygn. L. dział IV.2: 36.

18 ADS, sygn. L. dział IV.2: 36, 58, 78.

${ }^{19}$ ADS, sygn. L. dział IV.2: 61.
} 
the priests arriving in large numbers to celebrate the indulgence feasts. The fate of the other movable property is not known ${ }^{20}$.

The church building remained intact until it was damaged by a strong wind during a snowstorm on 27 December 1868. The damage to the roof was so substantial that Józef Pruszkowski, the head of the Konstantynów deanery, wrote in his report that 'only trusses and rafters were left standing on the church'. The statue of Mother of God fell from the roof top and got damaged ${ }^{21}$. The main nave was sheltered with new sheet metal and the damaged metal covering on the chapels was financed from the private funds of parish administrator Fr Przesmycki. He made unsuccessful attempts to recover money from the state Treasury ${ }^{22}$.

On 18 April 1875, Warsaw's Governor General Paweł Kotzebue, acting upon Tsar Alexander II's order of 6 April 1875, announced his decision to seize the temple in Leśna Podlaska from the Roman Catholic Church and give it to the Eastern Orthodox Church for 'Greek Uniates in communion with the Eastern Orthodox Church'. The order included a disposition to hand over, together with the church building, the worshipped image of Our Lady with the great altar and votive offerings (the inventory of 3 December 1864 records, among other things, silver votive offerings encircling the painting: 2 square, 8 inches; 3 square 5 inches; 51 other, square; 2 triangular, 2 oval, 3 triangular, 44 large, the shape not specified, 11 small hearts, 2 double hearts, 10 hands, 22 legs, 1 eye, 3 heads, 1 shield, 4 rings, a large silver medal, a gilded medal on a chain, a canon's chain with a distinctorium, a gold pin with 3 gems, a gold ring with 5 garnets, a small gold heart, a small gilded crucifix, a cross made of 'crown-gold dressed in gold', a gold cross with pearls, gold bead clasp with 21 garnets, a medallion with Our Lady 'of Paris', medallions of French gold, 14 long coral strings, 34 long coral strings, 2 strings of garnets, 2 strings of amber beads, gilded gems around a painting, a crown of gilded gems, a dress 'adorned with gems and pearls', 2 silver crowns encrusted with pearls on the sides of a painting, a 'silver spread' to decorate a painting).

The precisely formulated instruction confirms the aspirations to take over not only the material assets, but also the plans of the Orthodox Church to continue the tradition of the Marian cult centre, which is popular among the faithful of both rites. These activities were an element of the strategy of introducing Eastern Orthodoxy in the lands of the Kingdom of Poland.

Simultaneously with the decision to take over the church in Leśna, an order was issued to remove the internal equipment used for Roman Catholic worship, especially the organ. Bishop of the Lublin Diocese Valentin Baranovsky was tasked with the execution of the order. The Russian authorities gave 300 roubles to cover

\footnotetext{
${ }^{20}$ ADS, sygn. L. dział IV.2: 62-69.

${ }^{21}$ ADS, sygn. L. dział IV.2: 59.

${ }^{22}$ ADS, sygn. L. dział IV.2: 157-166.
} 
the transportation cost via the Lublin governor. The time for the execution of the order was very short. The celebration of the first Orthodox liturgy was planned for Pentecost falling on 23/11 May 1875 in the liturgical calendar of the Eastern Orthodox Church ${ }^{23}$.

The bishop delegated a canon of the Lublin cathedral, Fr Michał Antulski, to supervise the removal of the equipment of the Leśna church. He was ordered to dispatch some of the movables back to Lublin relying on the property register included in the inventory, and to hand over the remaining movables against a receipt to pastors or administrators of other parishes. Fr Józef Pruszkowski, the dean of Konstantynów, was obliged to disseminate among the parish clergy information about the possibility of taking over the equipment from the church in Leśna ${ }^{24}$. The bishop instructed Fr Antulski to draw up a report on the activities carried out in the presence of a representative of the local manor and Fr Pruszkowski ${ }^{25}$.

The removal of the church equipment proceeded in haste. On 12 May, Fr Antulski packed 'the apparatus and other church instruments of greater value' first in three crates, and together with a parcel with some other church equipment put them on two wagons to go to Lublin, in the hands of the bishop. Fr Antulski did not include any inventories, contrary to the recommendation because - as he explained - 'he had no time to write down such inventories, ${ }^{26}$.

For one thing, the removal of the equipment was difficult because the time for it was short, but there was also a shortage of people willing to work. As Fr Antulski recalls: 'ten men can only handle a confessional, while the poor people are lamenting but no none will touch a thing'; and local craftsmen had fled so that they would not be bothered removing the church equipment ${ }^{27}$. Three carpenters and two joiners were brought in from at least a dozen kilometres away to do the job: Biała Podlaska, Janów Podlaski, Międzyrzec Podlaski, Łosice, and Sarnaki. Since the residents of Leśna Podlaska refused to help remove the heavy items of equipment from the church, some Cossacks worked for four days and were paid for their work. The removal was carried out in the presence of Russian gendarmes and three units of Cossacks ${ }^{28}$. There was not enough space to store the furnishings removed from the church interior. Six large confessionals and church benches were put outside ${ }^{29}$.

The coordination work of Fathers Antulski and Pruszkowski was interfered with by Orthodox clergymen who had come from Galicia and made it impossible to remove the side altars from the church and 'denied the right to remove the pulpit [...], not only did they not allow the church wardrobes, chests of drawers, wall pictures and many other objects to be taken away, but they also took possession of the silver cross

\footnotetext{
${ }^{23}$ ADS, sygn. L. dział IV.2: 84-85.

${ }^{24}$ ADS, sygn. L. dział IV.2: 86.

${ }^{25}$ ADS, sygn. L. dział IV.2: 87-88.

${ }^{26}$ ADS, sygn. L. dział IV.2: 96.

${ }^{27}$ P.J.K. Podlasiak [PRUSZKOWSKI] 1897: 96-97.

${ }^{28}$ ADS, sygn. L. dział IV.2: 96, 108.

${ }^{29}$ ADS, sygn. L. dział IV.2: 105.
} 
with relics of saints, all of the twenty-four precious candlesticks, the lavabo, crosses, church ropes, bells [...]'. They also did not allow the removal of paintings evaluated as 'beautiful' of St Paul the Hermit, St Casimir, and a small damaged painting of St Barbara ${ }^{30}$.

The most difficult task was to disassemble the huge organ (it had 24 voices, a pedal board, 2 keyboards, drums, 6 bellows), founded in the mid- $18^{\text {th }}$ century by Prince Karol Stanisław Radziwiłł. The attempts of Fr Antulski to postpone its removal were in vain, and he wrote about the refusal to the bishop on 12 May 1875: 'I was unable to have the military delegation leave this magnificent and extremely expensive organ of enormous size intact at your Excellence's disposal'. The instrument was disassembled by Fathers Antulski and Pruszkowski. At a later stage, they were joined by the local organist ${ }^{31}$. The disassemblers were aware of the historical value of the organ, its symbolic importance for the local residents, and its uniqueness on account of its sheer size. They tried to carefully place the parts of the instrument in the shed and the monastery building. However, the organ pipes were so large that they did not fit into post-monastery cells. Six huge bellows were left in the church for lack of storage space ${ }^{32}$. The workers were aware of the irreparable destruction of both the ornaments of the organ casing and the organ box and pipes. In his report, Fr Antulski noted: 'a magnificent structure with all ornaments is now almost destroyed due to the hasty dismantling ${ }^{33}$. The dismantlers made a realistic assessment of the value of the instrument in various aspects: as a valuable historical monument, but with a clear and important message only at a local level. They also found that the organs were too large and heavy to be considered a valuable instrument in the modern world ${ }^{34}$. The information about the dismantled organs reached as far as Warsaw. Due to the significant material and historical value, the priests of All Saints Church located at Grzybowski Square in Warsaw asked the instrument to be donated to them. The decision to transfer the instrument to Warsaw was issued by the Lublin Diocesan Bishop. On 11 June, 1875, along with the elements of the organ, 12 tin candlesticks, 2 copper drum cases and 1 oak confessional were transferred to the Warsaw church ${ }^{35}$.

The remaining items of the church equipment were moved to parish churches of the dissolved diocese of Podlasie. First of all, to the nearest parishes:

\footnotetext{
${ }^{30}$ ADS, sygn. L. dział IV.2: 99.

${ }^{31}$ ADS, sygn. L. dział IV.2: 108.

${ }^{32}$ ADS, sygn. L. dział IV.2: 96, 104-105; PRUSZKOWSKI 1897: 94-95.

${ }^{33}$ ADS, sygn. L. dział IV.2: 105.

34 Dean Pruszkowski explained his reasons in the correspondence addressed to Bishop Walenty Baranowski in the following way: 'The huge Radziwiłł organ became a heap of utter ruin [...] no church will accept it, and its inner value can only be assessed by organ masters as material for other organs. All of the wooden elements and as many as 6 bellows will not even serve as material; everything is huge and heavy and impractical for today's times, and destroyed besides; is means something only as a memento of the Radziwiłł donation and only locally in Leśna'. ADS, sygn. L. dział IV.2: 99.

${ }^{35}$ ADS, sygn. L. dział IV.2: 119-120; PRUSZKOWSKI 1897: 117-118.
} 
in Bordziłówka (chasubles: white, purple, black), Janów Podlaski (a white chasuble, white cape), Kąkolewnica (4 old worn chasubles, 3 old worn masses, 2 wooden crosses, tin and wooden candlesticks, old albs, and other small items of underwear) ${ }^{36}$. Other items of the equipment were handed over to parishes whose pastors submitted written petitions, mostly motivated by the poor material condition of the parishes and insufficient church equipment. Temporarily, some of the equipment was deposited in the bishop's seat of the dissolved Podlasie diocese in Janów Podlaski.

On 15 June, 1875, Fr Adam Byszewski, the pastor of the parish in Tuchowicz (Siedlce Governorate, Poviat of Łuków), where a church was being erected after a fire consumed the previous one, came to Leśna Podlaska to collect 5 chasubles 'in an average condition', an iron mould for baking wafers, old drum, 2 oak confessionals, 2 smaller confessionals, baptismal font with a copper kettle, old canopy, brass lavabo, and an umbraculum ${ }^{37}$. On 14 July 1875, the church in Sokołów Podlaski (Siedlce Governorate, Poviat of Sokołów) - following the efforts of the local parish priest who wanted to decorate the modest interior of the church - received 4 sculptures of angels and several sculptures, whose appearance was not described, to adorn the altar in the place of the missing sculptures on the pedestals ${ }^{38}$. On 14 July 1875 , the parish priest of the Ceranów parish (Siedlce Governorate, Poviat of Sokołów) personally received 2 oak confessionals and 4 wooden figures ${ }^{39}$. Also on 14 July 1875, the pastor of the Pruszyn parish (Siedlce Governorate, Poviat of Siedlce), Aleksander Skorupka, took over 2 confessionals, 10 oak benches, a pyx from the great altar, 20 larger and smaller figures, 8 tin candlesticks, a canopy, a figure of the Risen Christ, an oil painting and 2 feretrums for processions, and 2 wooden sculptures of Jesus, one of which he planned to donate to the church in Łuków (Siedle Governorate, Poviat of Łuków) ${ }^{40}$. At the request of the pastor of the Serokomla parish (Siedlce Governorate, Poviat of Łuków), Fr Andrzej Wajewski, the following chasubles were handed over to the local church: white, purple, black, red, 1 cape, 1 alb, 3 tablecloths, and 2 towels ${ }^{41}$. The parish church in Zbuczyn (Siedle Governorate, Poviat of Siedlce) received 2 large confessionals, 10 benches, the pyx from the great altar, 20 larger and smaller altar figures, 8 tin candlesticks, a canopy, the stalls from the chancel, and a resurrection figure $^{42}$. Several cloths, probably previously donated by the faithful of the Leśna parish, were handed over to women from the rosary fraternity of Leśna Podlaska (10 curtains, 4 humeral veils and other smaller items $)^{43}$.

\footnotetext{
${ }^{36}$ ADS, sygn. L. dział IV.2: 104-105.

${ }^{37}$ ADS, sygn. L. dział IV.2: 139.

${ }^{38}$ ADS, sygn. L. dział IV.2: 141.

${ }^{39}$ ADS, sygn. L. dział IV.2: 137.

${ }^{40}$ ADS, sygn. L. dział IV.2: 138.

${ }^{41}$ ADS, sygn. L. dział IV.2: 118.

${ }^{42}$ PRUSZKOWSKI 1897: 116-117.

${ }^{43}$ ADS, sygn. L. dział IV.2: 104-105.
} 
Liturgical utensils which ended up in Lublin were donated. The beneficiaries were both parishes of the dissolved the Podlasie diocese, as well as the Diocese of Lublin. Most of the silverware (a silver monstrance, silver chalice, four gilded chalices, silver paten, silver lamp) and liturgical vestments (white cape; purple cape embroidered with silver; chasubles: 5 white, 3 red, including 1 velvet chasuble, violet and green) was handed over to the parish in Tuchowicz mentioned above. The next parish donated the silverware of the Post-Pauline church was one in the liquidated the Podlasie diocese in Kąkolewnica (silver items: a monstrance, pyx, chalice, paten). The other movable items (vessels, books, vestments) were transferred to churches in Lublin: St John of God (1 silver paten; chasubles: 3 white, 2 red, 1 violet), the PostBernardine church (missal), seminary church ( 2 white ones, 1 red one, 1 green one, and 1 dalmatic), to St Nicholas Church on Czwartek Hill (chasubles: 1 white, 1 violet, 2 red, 1 black one), and the church in Firlej (chasubles: 3 white, 1 red, 1 black, and 2 dalmatics $)^{44}$.

After this stage of equipment removal in the Leśna Podlaska church, 5 side altars and the pulpit were left intact; so were some paintings, the removal of which was opposed by the Orthodox clergy present during the removal: the painting of the Visitation of the Blessed Virgin Mary, St Paul the Hermit, St Casimir, St Thecla (which, as Fr Pruszkowski commented, depicted the saint 'in a today's style, gaudy, looking like fashionable dresser') and a dilapidated image of St Barbara ${ }^{45}$. It seems that the decision to keep them was based on the evaluation of their artistic value, and their content. Their subject matter was not typical of the iconography of the Orthodox Church circles.

The largest controversy was caused by the painting of the Visitation of St Elisabeth by the Blessed Virgin Mary mounted on the sliding screen in the central altarpiece. The bishop petitioned the Governor General ${ }^{46}$ several times for its recovery, arguing that the image on the screen was unnecessary in the worship of the Orthodox Church. The painting was considered to be a work of extraordinary artistic value and a memento of Szymon Czechowicz's mastery ${ }^{47}$. It was a misconception. Nowadays, the authorship of the image, painted around 1772, is attributed to Jan Bogumił $\mathrm{Plersch}^{48}$. The bishop's requests were unsuccessful. The Orthodox faithful kept the painting in the Leśna church. It seems that artistic merits were decisive in this respect, and the idea of preserving the integrity of the great altar was of utmost importance. The preservation of the altar without any visual changes was expected to make it easier to continue the worship of the image of Our Lady of Leśna, even at

\footnotetext{
${ }^{44}$ ADS, sygn. L. dział IV.2: 143-148.

${ }^{45}$ ADS, sygn. L. dział IV.2: 104-105.

${ }^{46}$ ADS, sygn. dział III, Z, Akta Ogólne, Zakon oo. paulinów w Leśnej, t. 1, nr 6: 4.

${ }^{47}$ ADS, sygn. L. dział IV.2: 127.

${ }^{48}$ KOLENDO-KORCZAKOWA, OLEŃSKA, ZGLIŃSKI 2006: 150-159.
} 
the price of departing from the traditional canon. Also, a gold-framed painting of St Philomena was left, evaluated as a 'fairly good"49.

The process of taking over the furnishings of the Post-Pauline church lasted a few more years. In 1878, a search for the cross with the relics of St Thecla was conducted at the request of the Lublin bishop. After the bishop's three firm interventions with the Governor General, the Orthodox faithful returned the large silver cross with the relics of St. Tekla, its arms decorated at ends with gold-plated medallions of the Four Evangelists ${ }^{50}$. On May 4, 1878, the cross was collected from the Leśna church by Fr Pióro from the nearby parish of Bordziłówka and then handed over to Lublin via Janów. In transit, when the wagon overturned, the cross got broken $^{51}$.

On September 30, 1878, after the intervention of the Governor of Siedlce with the Bishop of Lublin, the items left in the sacristy of the church were collected, usually in a poor condition ( 3 bells, 28 candlesticks, procession cross, lead lavabo, tray, paintings, flags, clock, dust brushes, armchair, stools, catafalque, a cross placed at the relics of St Thecla, thurible, collection boxes) ${ }^{52}$. Some of the items, considered more valuable, both in material and artistic terms, were sent to the bishop in Lublin ( 3 bells from the tower, 28 candlesticks, procession cross, lead lavabo, silver thurible, silver navicula with a spoon, tray, an old picture of St Mark - described by Fr Pruszkowski as 'the best of all') $)^{53}$. The other items of the equipment were donated to the church in Sarnaki (Siedlce Governorate, Poviat of Konstantynów) (one small painting 'of some value'), in Bordziłówka (small candlesticks, 2 dilapidated paintings), and in Janów Podlaski (2 old rugs, 2 chandeliers, and a new standing cross). By the decision of Fr Pruszkowski, one dilapidated picture was given to a parishioner from Bordziłówka as 'a souvenir' ${ }^{54}$.

The next stage in the distribution of the equipment of the Post-Pauline church in Leśna Podlaska started after the commencement of construction works related to the transformation of the church. On 12 June 1879, the Governor of Siedlce informed the bishop about the possibility of collecting the side altars and other church equipment ${ }^{55}$.

In 1879, the newly built church in Tuchowicz was donated other furnishings: 5 side altars, pulpit, baptismal font, wardrobes, and an armchair ${ }^{56}$. By the bishop's decision, some tower bells, 22 candlesticks, procession cross, and a tin lavabo with

\footnotetext{
${ }^{49}$ ADS, sygn. dział III, Z, Akta Ogólne, Zakon oo. paulinów w Leśnej, t. 1, nr 6: 4.

${ }^{50}$ ADS, sygn. dział III, Z, Akta Ogólne, Zakon oo. paulinów w Leśnej, t. 1, nr 6: 4.

51 ADS, sygn. L. dział IV.2: 133-135.

${ }^{52}$ ADS, sygn. L. dział IV.2: 149-150.

${ }^{53}$ ADS, sygn. dział III, Z, Akta Ogólne, Zakon oo. paulinów w Leśnej, t. 1, nr 6: 3.

${ }^{54}$ ADS, sygn. L. dział IV.2: 151-152.

${ }^{55}$ PRUSZKOWSKI 1897: 122-123.

${ }^{56}$ ADS, sygn. dział III, Z, Akta Ogólne, Zakon oo. paulinów w Leśnej, t. 1, nr 6: 3.
} 
a tray were conveyed to Lublin, while some chandeliers went to the church in Janów Podlaski ${ }^{57}$.

In 1879, the altar painting of St Paul the Hermit was also sent to Lublin by train, which was perhaps caused by the discovery that it was not a work by Czechowicz, as the Paulines erroneously asserted, but by Michał Stachowicz ${ }^{58}$, a Kraków artist, painted in 1802. It seems that the recognition of the value of a 'memento' was determined by a conviction that the painting was created before the Partitions.

The book collection of the Leśna Pauline monks, containing about 500 items, remained in place after the dissolution and was secured by the authorities. Bishop of Podlasie Beniamin Szymański did not manage to carry out the instruction of the Government Commission of Internal and Church Affairs, which ordered to place the library in the seminary, because the diocese was liquidated by Tsar Alexander II's ukaz of 22 May 1867, and its territory was annexed to the Diocese of Lublin. As a result of the sluggishness of the Lublin diocese administrator, Fr Kazimierz Sosnowski, the books were transferred to the library of the seminary in Lublin only at the beginning of the $1880 \mathrm{~s}^{59}$.

In the years 1879-1881, the Leśna church was renovated, during which its architectural design was changed by lowering the towers and crowning the them with five domes, giving the building the appearance characteristic of Orthodox Church churches. A division into three naves and a choir was maintained. The great altar was restructured, but a passage was left behind it to allow pilgrims to circumvent the altar as it was done in the past. As a result, the iconostasis did not span the walls. The paintings showing the Visitation of the Blessed Virgin Mary and St Philomena were retained. On 11 June/31 May 1881, the Orthodox Bishop of Chełm-Warsaw Leontyi solemnly consecrated the church. In 1884, the church and the monastery were handed over to a female religious community from Grodno Governorate, headed by Superior Countess Eugenia Borysova Efimowska. Initially, the establishment operated as a monastery, then as a lavra. To cater for the needs of the nuns, who were active in many fields, the complex of monastery buildings was extended. The source of financing for the bold investments were grants made by the Russian authorities ${ }^{60}$, and donations from Orthodox clergy and lay faithful $(1894)^{61}$, including representatives of the social elite, such as an artist of Moscow Theatre and his family $(1897)^{62}$. The construction investments in Leśna Podlaska were supervised by the Technical-

\footnotetext{
${ }^{57}$ PRUSZKOWSKI 1897: 122-123.

58 ADS, sygn. L. dział IV.2: 153.

${ }^{59}$ In 1845 the library had 464 items in 587 volumes. Archiwum paulinów na Jasnej Górze, rps 1622 (kopia w zbiorach Ośrodka ABMK w Lublinie, mf 1799) [brak paginacji]; ZALEWSKI 1926: 15-17; BIEŃKOWSKA 1988: 400-414.

${ }^{60}$ APL, Chełmski Zarząd Duchowny, sygn. 1564, 1732, 1819 [brak paginacji].

${ }^{61}$ APL, Chełmski Zarząd Duchowny, sygn. 706 [brak paginacji].

${ }^{62}$ APL, Chełmski Zarząd Duchowny, sygn. 7049 [brak paginacji].
} 
Building Committee for Economic Administration at the Holy Synod in St Petersburg ${ }^{63}$.

In the hands of the Orthodox nuns, the monastery operated for thirty years until their evacuation in the summer of 1915. At that time, the nuns, with the support of the highest state and church authorities, conducted lively religious activities (promoting Orthodoxy among the former Uniate population), cultural and educational (Russification work among the local rural population), caring and economic. The activity of the Leśna nuns contributed to the implementation of the policy of the Russian state and the Orthodox Church. In the actions taken, nuns transferred to Podlasie the models of Russian Orthodoxy, at the same time eliminating Ruthenian (Belarussian, Ukrainian) traditions. In their educational, cultural, caring and economic activities, they drew on the experience of renowned Russian teachers and scholars ${ }^{64}$.

The analysis of the processes of taking over buildings and equipment by the Eastern Orthodox Church after the Pauline monastery in Leśna Podlaska, closed in 1864, showed that the promotion of the Orthodox religion was an important element of Russification in the Russian policy towards the lands of the Kingdom of Poland.

After the Orthodox nuns left Leśna Podlaska in 1915 as a result of the events of World War I, the Roman Catholic parish was restored there. The monastery buildings had been devastated by the German troops. After a few months without any residents there were no doors, no windows, and the stoves were dismantled ${ }^{65}$. On February 21, 1917, a teachers' college was established in the former monastery buildings on an initiative of the Polish Schooling Society. At the turn of April 1919, the Pauline monks returned to Leśna Podlaska. On October 27, 1919, a conference on the division of the buildings and the land was held at the Department of Religious Denominations of the Ministry of Religious Denominations and Public Enlightenment in Warsaw, with the participation of Bishop of Podlasie Henryk Przeździecki, Bishop Adolf Szelążek and representatives of the Ministry. A border was marked out (the document used the term 'demarcation line' - the terminology may indicate difficult negotiations) between the property of the Pauline Order and the Ministry of Religious Denominations and Public Enlightenment, the latter promising to finance a fence. The monks took over 2 big ponds, 4 pools, a fruit garden, some arable land and meadows ${ }^{66}$. This did not prevent long-term conflicts, also in respect of the use of the park ${ }^{67}$. The college remained in the former monastery buildings, although the monks believed that its presence would prevent them from living according to their religious rule ${ }^{68}$. The monks dealt with the reconstruction of the church building.

\footnotetext{
${ }^{63}$ APL, Chełmski Zarząd Duchowny, sygn. 1819: 6-9.

${ }^{64}$ CABAJ 2018: 37-75. DMITRUK 2009: 79-80.

${ }_{65}^{65}$ ADS, sygn. dział III, Z, Akta Ogólne, Zakon oo. paulinów w Leśnej, nr 6: 64.

${ }^{66}$ APL O/R, Państwowe Seminarium Nauczycielskie w Leśnej Podlaskiej, sygn. 103, Skargi dotyczące zatargu Państwowego Seminarium Nauczycielskiego w Leśnej Podlaskiej z zakonem oo. Paulinów: 22-28.

${ }^{67}$ ADS, sygn. dział III, Z, Akta Ogólne, Zakon oo. paulinów w Leśnej, nr 6: 42-43, 122.

${ }^{68}$ ADS, sygn. dział III, Z, Akta Ogólne, Zakon oo. paulinów w Leśnej, nr 6: 64.
} 
In 1923-1925 the domes were removed, and in 1927, according to the design of one of the most distinguished Polish architects of the first half of the twentieth century, Adolf Szyszko-Bohusz, the façade and towers were rebuilt, and a third storey and a roof bell were added. In 1937, due to structural reasons, the brick structures were replaced with wooden ones, drawing on the original design which predated the reconstruction ${ }^{69}$.

Of the former equipment of the church which had been handed over to at least 18 churches, the Late Baroque sculptures of Paul the Hermit and Anthony the Abbot and a pax reliquary with the relics of St Thecla returned from the church in Sokołów Podlaski in $1919^{70}$. The memory of all the other items of mobile equipment has been obliterated by time ${ }^{71}$. The organ donated to All Saints Church in Warsaw was destroyed in 1944 during the Warsaw Uprising.

The cult of the image of Our Lady of Leśna continues both in the sanctuary of Leśna Podlaska and in France, where the nuns from the monastery in Leśna Podlaska ended up via St Petersburg, Bessarabia and Serbia (1915-1950), now living in the village of Chauvincourt-rovemont since 1967.

\footnotetext{
${ }^{69}$ APL, Urząd Wojewódzki Lubelski, [Projekt odbudowy wież w Leśnej Podlaskiej], sygn. 345: 3-4; IWANEK 2011: 113-143.

${ }^{70}$ KOLENDO-KORCZAKOWA, OLEŃSKA, ZGLIŃSKI 2006: 150-159.

${ }^{71}$ It can be assumed that 6 tin candlesticks in Pruszyn listed in the Catalogue of Monuments may come from Leśna Podlaska. GALIŃSKA, SYGIETYŃSKA 1965: 23. 


\section{Bibliography}

\section{Sources}

ADS - Archiwum Diecezjalne w Siedlcach:

sygn. 432, 436, dział III, Z, Akta Ogólne, Zakon oo. paulinów w Leśnej, t. 1, nr 6, L. dział IV. 2, Akta konsystorza generalnego diecezji lubelskiej. Fundusze budowle cmentarze kościoła parafialnego popaulińskiego w Leśnej, t. 1.

AGAD - Archiwum Główne Akt Dawnych, Warszawa:

Centralne Władze Wyznaniowe, sygn. 239.

APL - Archiwum Państwowe w Lublinie:

Chełmski Zarząd Duchowny, sygn. 706, 1564, 1732, 1819, 7049.

Urząd Wojewódzki Lubelski, sygn. 345.

APL O/R - Archiwum Państwowe w Lublinie, oddział w Radzyniu Podlaskim:

Państwowe Seminarium Nauczycielskie w Leśnej Podlaskiej, sygn. 103.

Archiwum paulinów na Jasnej Górze (kopia w zbiorach Ośrodka ABMK w Lublinie):

rkps 1622 (ABMK w Lublinie mf 1799).

P. J. K. Podlasiak [PRUSZKOWSKI J.] (1897), Historya zjawionego i cudownego obrazu Matki Boskiej oraz kościoła i probostwa w Leśnej na Podlasiu zabranego na własność prawostawia, Kraków.

\section{Literature}

BIEŃKOWSKA B. (1988), 'Biblioteka OO Paulinów w Leśnej (1727-1864)', Studia Claromontana 9, 400-414.

BOSIACKA A. (2006), 'Leśniańska Księga Cudów 1683-1768’, Barok 1, 207-236.

CABAJ J. (2018), 'W służbie prawosławia i państwa rosyjskiego - działalność mniszek leśniańskich na obszarze nadbużańskiego Podlasia na przełomie XIX i XX wieku', Niepodlegtość i Pamięć 25.4 (64), 37-75.

DMITRUK S. (2015), 'Dom bazylianów i parafia unicka w Radecznicy (1869-1875)', Res Historica 39, 113-132.

DMITRUK S. (2009), 'Żeńskie monastery prawosławne na terenie Królestwa Polskiego na przełomie XIX i XX w.', Teka Kom. Hist. OL PAN 6, 73-84.

GACH P. P. (1984), Kasaty zakonów na ziemiach dawnej Rzeczypospolitej i Śląsa 1773-1914, Lublin.

GALIŃSKA I., SYGIETYŃSKA H., ed. (1965), Katalog zabytków sztuki w Polsce, 10: Województwo mazowieckie, z. 25: Powiat siedlecki, Warszawa.

IWANEK M. (2011), 'Projekty architektoniczne Adolfa Szyszko-Bohusza dla kościoła paulinów w Leśnej Podlaskiej', Roczniki Humanistyczne 59.4, 113-143.

KOLENDO-KORCZAKOWA K., OLEŃSKA A., ZGLIŃSKI M., ed. (2006)., Katalog Zabytków Sztuki w Polsce, 8: Województwo lubelskie, z. 2: Powiat Biała Podlaska, Warszawa.

MARAŚKIEWICZ J. (1983), Leśna Podlaska. Architektura kościoła, Biała Podlaska.

PREJS R. (2014), 'Kasata klasztorów na Śląsku w 1810 r. a kasata klasztorów w Królestwie Polskim w 1864 r.. Podobieństwa i różnice', in: Kasaty klasztorów na obszarze dawnej Rzeczypospolitej Obojga Narodów i na Ślasku na tle procesów sekularyzacyjnych w Europie, t. I, Geneza. Kasaty na ziemiach zaborów austriackiego i rosyjskiego, ed. M. DERWICH, Wrocław, 369-383.

WEREDA D. (2013), 'Zaangażowanie szlachty i magnaterii $\mathrm{w}$ tworzenie sanktuarium w Leśnej Podlaskiej’, Szkice Podlaskie 19/20, 319-330. 
WIECH S. (2015),' Kasata klasztorów w Królestwie Polskim w 1864 r. w świetle wspomnień i relacji Dmitrija Anuczina', in: Życie zakonne w Królestwie Polskim w latach 1832-1864. Polityka caratu-KasatyRepresje, eds. W. GRACZYK, J. M. MARSZALSKA, Kraków, 9-36.

WRZESZCZ M., ZBUDNIEWEK J. (2004), 'Leśna Podlaska', Encyklopedia Katolicka 10, 868-870.

ZALEWSKI L. (1926), Bibljoteka seminarjum duchownego $w$ Lublinie i bibljoteki klasztorne $w$ diecezji lubelskiej i podlaskiej, Warszawa.

ZBUDNIEWEK J. (1988), 'Fundacja parafii i klasztoru paulinów w Leśnej', Studia Claromontana 9, 388-393. 